\title{
Cervical shaping in curved root canals: comparison of the efficiency of two endodontic instruments
}

\section{Desgaste cervical em canais curvos: comparação entre a eficiência de dois instrumentos endodônticos}

\author{
Sandra Soares Kühne Busquim* \\ Marcelo dos Santos**
}

\begin{abstract}
The aim of this study was to determine the removal of dentin produced by number $25(0.08)$ Flare files (Quantec Flare Series, Analytic Endodontics, Glendora, California, USA) and number 1 e 2 Gates-Glidden burs (Dentsply - Maillefer, Ballaigues, Switzerland), in the mesio-buccal and mesio-lingual root canals, respectively, of extracted human permanent inferior molars, by means of measuring the width of dentinal walls prior and after instrumentation. The obtained values were compared. Due to the multiple analyses of data, a nonparametric test was used, and the Kruskal-Wallis test was chosen. There was no significant difference between the instruments as to the removal of dentin in the $1^{\text {st }}$ and $2^{\text {nd }}$ millimeters. However, when comparing the performances of the instruments in the $3^{\text {rd }}$ millimeter, Flare files promoted a greater removal than Gates-Glidden drills ( $p>0.05)$. The analysis revealed no significant differences as to mesial wear, which demonstrates the similar behavior of both instruments. Gates-Glidden drills produced an expressive mesial detour in the $2^{\text {nd }}$ and $3^{\text {rd }}$ millimeters, which was detected trough a statistically significant difference in the wear of this region ( $p>0.05)$. There was no statistically significant difference between mesial and lateral wear when Flare instruments were employed.
\end{abstract}

DESCRIPTORS: Dental pulp cavity; Root canal preparation; Dental instruments.

RESUMO: O propósito do presente trabalho foi determinar o desgaste promovido em dentina pelas limas Flare número 25 (0,08) (Quantec Flare Series, Analytic Endodontics, Glendora, Califórnia, EUA) e pelas brocas Gates-Glidden números 1 e 2 (Dentsply-Maillefer, Ballaigues, Suíça), nos canais mesiovestibular e mesiolingual, respectivamente, de molares inferiores permanentes humanos extraídos, através da medição, em milímetros, da espessura das paredes dentinárias antes e posteriormente à instrumentação. Os valores dos desgastes obtidos foram comparados entre si. A análise dos resultados, baseada no teste estatístico não-paramétrico de Kruskal-Wallis, demonstrou não haver diferença estatística significante entre o desgaste lateral provocado pelos instrumentos avaliados no primeiro e segundo milímetros, enquanto que no terceiro milimetro observou-se maior desgaste realizado pelas limas Flare $(\mathrm{p}>0$,05). Em relação ao desgaste mesial, um comportamento semelhante dos instrumentos avaliados foi observado, estatisticamente não significante. As brocas Gates-Glidden demonstraram um desvio para mesial no segundo e terceiro milímetros, detectado pela diferença estatisticamente significante $(\mathrm{p}>0,05)$ do desgaste nesta direção. As limas Flare não demonstraram diferença estatisticamente significante de desgaste quando se comparou as direções mesial e lateral.

DESCRITORES: Cavidade da polpa dentária; Preparo de canal radicular; Instrumentos odontológicos.

\section{INTRODUCTION}

The success of the endodontic treatment is based on the access to the pulp chamber, on the preparation of the root canal and on its hermetic obturation, which must avoid infection or reinfection. Therefore, scientific knowledge and professional skills are essential requisites for the dentist to act within the root canal, without interfering with the process of tissue repair ${ }^{1,6,10,14,15,16,17,20}$.

Cleaning and shaping are the two main objectives of canal preparation. The first procedure con- sists in the elimination or reduction of tissue remnants, as well as of bacteria and their byproducts. Shaping consists in promoting the conical enlargement of the canal. Therefore, there is a co-relation between both procedures, and the effort necessary to carry them out depends on the internal anatomy of the root, which might present with curves and irregularities ${ }^{6,8}$.

In order to reduce difficulties, especially those related to the preparation of atresic and curved canals - which can lead to iatrogenicities such as apical zips, elbows, ledges and perforations -, new

\footnotetext{
*Dentist, Specialist in Endodontics.

**PhD, Professor, Discipline of Endodontics, Department of Restorative Dentistry, School of Dentistry, University of São Paulo.
} 
Busquim SSK, Santos M dos. Cervical shaping in curved root canals: comparison of the efficiency of two endodontic instruments. Pesqui Odontol Bras 2002;16(4):327-331.

techniques and endodontic instruments have been used. The obtainment of a straighter access to the root canal entry minimizes the possibility of errors and justifies the utilization of different instrumentation techniques. In one of them, the canal is initially enlarged on the cervical and medium thirds; projections and dentinal debris are removed and, afterwards, the apical third is prepared with less stress to the instrument, which minimizes the risk of fracture, and avoids flare-ups when dealing with necrotic pulps s,8,13,20. $^{3,}$.

Due to the fact that steel instruments are more rigid, nickel-titanium (Ni-Ti) instruments have gained space in the endodontic arsenal due to its great flexibility and "elastic memory". It fulfills the requirements for instrumentation of curved canals: resistance to fractures and flexibility ${ }^{2,11,19}$.

The utilization of mechanical preparation techniques with new-designed Ni-Ti instruments has contributed to reduce the difficulties related to strictly manual preparation, as well as the fatigue of the material and professional ${ }^{7}$.

There are various studies in the literature ${ }^{2,3,4,6.6}$ ${ }^{7,10,12,19}$ demonstrating the advantages of crown-down techniques with varied tapers, whose purpose is to prepare the coronal third, the anti-curvature and the conical conformation of root canals. On the other hand, there is need for a more careful evaluation of the obtained data, since the studies adopt various methodologies and, therefore, must be interpreted differently, avoiding generalizations.

The purpose of the present study was to determine the removal of dentin produced by number 25 0.08 Flare files (Quantec Flare Series, Analytic Endodontics, Glendora, California, USA), and by number 1 and 2 Gates-Glidden drills (DentsplyMaillefer, Ballaigues, Switzerland) on the mesio-buccal and mesio-lingual root canals of extracted human permanent inferior molars, through the measurement of the width of dentinal walls prior to and after instrumentation. The obtained values were compared.

\section{MATERIALS AND METHODS}

Nine extracted human inferior molars with intact pulp chambers were selected.

After external cleansing, the teeth were put in a $0.5 \%$ sodium hypochlorite solution for twenty-four hours, and were abundantly rinsed with water.

In order to improve the visualization of the cervical limit of teeth, a thin layer of black nail polish (Colorama, São Paulo - SP , Brazil) was applied on each root.
The coronary opening of each specimen was carried out with spherical diamond burs for high-speed hand-pieces (2, 4 and 6 - Labordental, São Paulo - SP, Brazil) according to the recommendations of Macedo ${ }^{11}$ (1998) and Di Donato ${ }^{5}$ (2000). Endo-Z burs (Maillefer, Ballaigues, Switzerland) were also used, but the operator carefully avoided touching the entrance of the root canal. Restorative materials and compromised dental tissue were completely removed.

Due to the necessity of embedding each tooth in resin for posterior transversal millimetric sectioning, pulp chambers were sealed with cotton and number 7 pink wax, placed with the aid of a number 7 spatula heated by means of an alcohol lamp.

The specimens were fixed by their occlusal surface in a piece of number 7 pink wax, and, on the proximal surfaces of each tooth, a metallic guide, previously protected by wax, was placed. This wax protection allowed their removal after the hardening of resin, preventing the misalignment of the resin blocks after the serial cuts were made.

After that, PVC blocks (with the diameter of $3 / 4$ inch and height of three centimeters) involved the tooth and metallic guides. Its borders were properly sealed with wax in order to keep the fluid polyester resin (Resinfiber, São Paulo - SP, Brazil) from overflowing. The resin was poured until the completion of the blocks. Each PVC tube was previously lubricated with Vaseline to simplify the removal of the resin blocks after the twenty-four hour curing period. Figure 1 shows the confection of resin blocks.

The metallic guides were removed from the resin blocks which contained the teeth, and each specimen was cut in three serial transversal sections along the coronal-apical extension of the tooth. The sections had approximately one millimeter in width, and were obtained by means of a Labcut 1010 microtome (Mitutoyo, Tokyo, Japan). Each section was properly numbered, and the width of dentin around the entrance orifice was measured by means of a Profile Projector PJ 3000 perfilometer (Mitutoyo, Tokyo, Japan). The distance between the most convex site of the root canal and the most distant external root surface, on the mesial and distal sides, was measured (Figure 2).

The blocks were rebuilt, the guides replaced, the wax and cotton removed and the mesial canals were explored with a number $10 \mathrm{~K}$ file.

The instrumentation of the mesio-buccal canal was carried out with a number 250.08 Flare file (Quantec Flare Series, Analytic Endodontics, Glendora, California, USA) activated by the Nou- 
Busquim SSK, Santos M dos. Cervical shaping in curved root canals: comparison of the efficiency of two endodontic instruments. Pesqui Odontol Bras 2002;16(4):327-331.

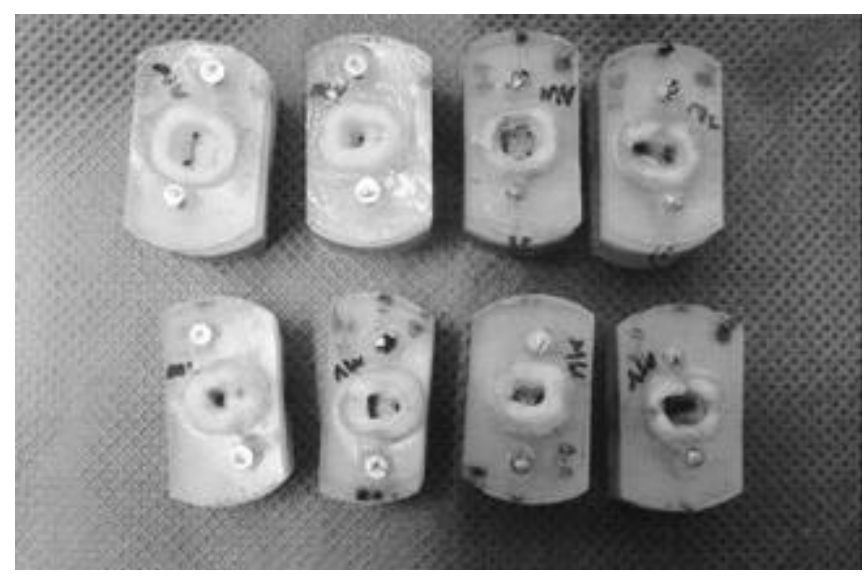

FIGURE 1 - Resin blocks.

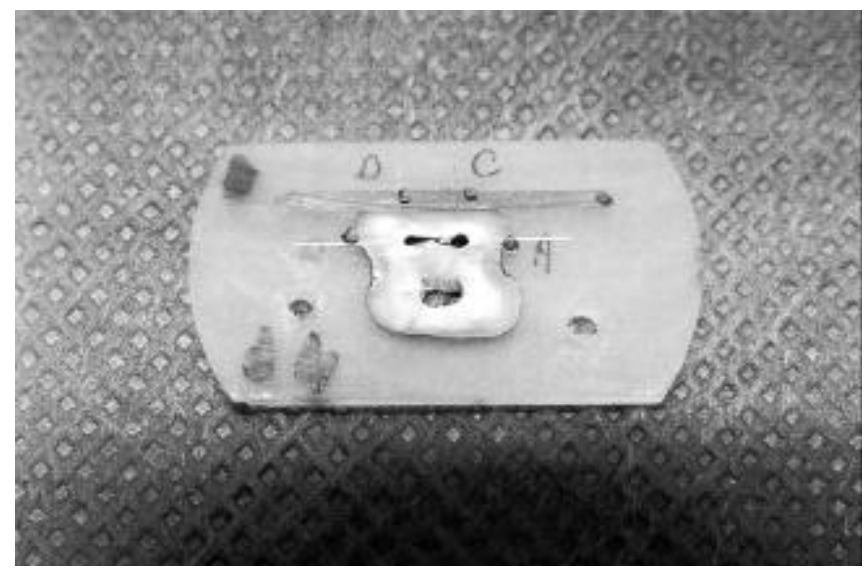

FIGURE 2 - Transversal section: A-C and B-D were measured, respectively, in the mesial-buccal and mesial-lingual canals, at the more convex site of the root canal.

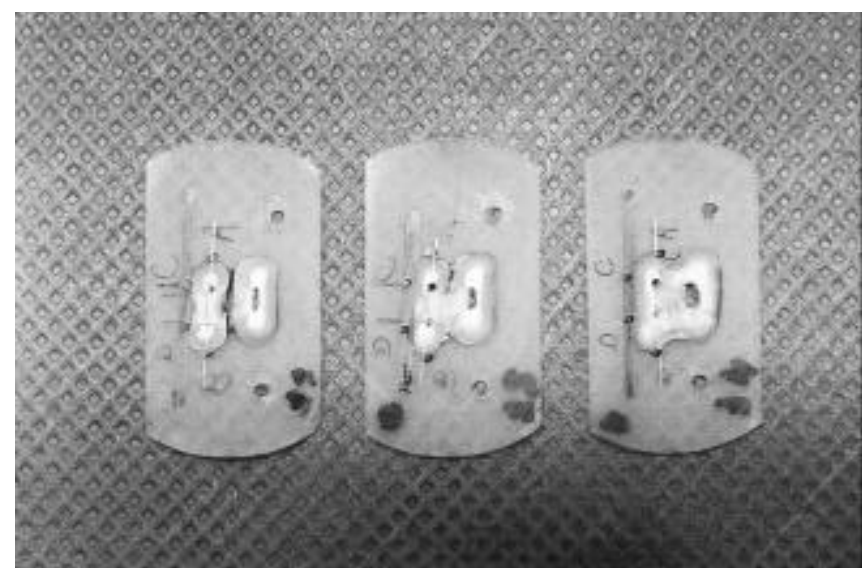

FIGURE 3 - Sections of specimen number 6.

vag TCM 3000 electrical motor (Nouvag ${ }^{\mathrm{TM}}$ AG, Goldach, Switzerland), at a constant speed of 250 rpm. Constant irrigation with $0.5 \%$ sodium hypochlorite was provided.
TABLE 1 - Mean values of mesial and lateral increase in three section levels.

\begin{tabular}{c|c|c|c}
\hline \hline Instrument & $\begin{array}{c}\text { Section } \\
\text { level }\end{array}$ & $\begin{array}{c}\text { Mesial increase } \\
(\mathrm{C}, \mathrm{D})\end{array}$ & $\begin{array}{c}\text { Lateral increase } \\
(\mathrm{A}, \mathrm{B})\end{array}$ \\
\hline \multirow{4}{*}{ Gates-Glidden } & 1 & 0.385 & 0.255 \\
\cline { 2 - 4 } & 2 & 0.255 & 0.235 \\
\cline { 2 - 4 } Flare & 3 & 0.358 & $0.164^{*}$ \\
\hline \multirow{4}{*}{} & 1 & 0.335 & 0.230 \\
\cline { 2 - 4 } & 2 & 0.223 & 0.205 \\
\cline { 2 - 4 } & 3 & 0.241 & $0.173^{*}$ \\
\hline \hline
\end{tabular}

*There was statistically significant difference (p > 5\%) when these groups were compared.

On the mesio-lingual canal, the number 1 and 2 Gates-Glidden drills were used with a low-speed handpiece (Dabi Atlante, Ribeirão Preto, São Paulo, Brazil). At each instrument change, irrigation with $0.5 \%$ sodium hypochlorite was carried out.

After root canal preparation, the blocks were separated and each section was measured again. The widths of dentin remnants were compared in order to evaluate the removal promoted by each instrument.

Figure 3 shows the three sections of specimen number 6 , after instrumentation, ready for the measurement of dentin removal.

\section{RESULTS}

The mean values of dentin removal obtained in the present study are presented in Table 1.

Comparing the distribution of data with a normal curve test, an abnormal distribution was found. Based on this information, a nonparametric test was used. The Kruskal-Wallis test was chosen, due to its multiple analysis.

There was no statistically significant differences between the dentin removal promoted by the different instruments in the $1^{\text {st }}$ and $2^{\text {nd }}$ millimeters. However, when comparing the performance of the instruments in the $3^{\text {rd }}$ millimeter, Flare files promoted greater removal than Gates-Glidden drills, with a significant difference of $5 \%$.

The analysis revealed no significant differences between groups $\mathrm{C}$ and $\mathrm{D}$ as to mesial increase, which demonstrates the similar behavior of both instruments as to mesial removal of dentin.

Gates-Glidden drills produced an expressive mesial detour ( $p>5 \%$ ), when the displacement towards lateral direction was analyzed. 
Busquim SSK, Santos M dos. Cervical shaping in curved root canals: comparison of the efficiency of two endodontic instruments. Pesqui Odontol Bras 2002;16(4):327-331.

Flare instruments demonstrated no statistically significant differences as to dentin removal towards mesial and lateral directions.

\section{DISCUSSION}

During root canal instrumentation, the maintenance of the original direction of the canals is of utmost importance, especially in curved canals, in order to promote a continuous and conical shape proper for obturation. This concept is defended by many authors such as Walton ${ }^{20}$ (1992), Nagy et al. $^{15}$ (1997); Marroquin ${ }^{13}$ (1996) and Thompson, Dummer $^{19}$ (1998).

Crown-down techniques allow pre-widening the coronal two thirds of the canal, providing a conical configuration without excessively increasing the width of the apical third. They are indicated for curved root canals because a straight-line access decreases the chances of debris extrusion, as well as of apical transportation and perforation, among other advantages (Leonardo, Leal ${ }^{10}, 1991$; Walton $^{20}, 1992$; Macedo ${ }^{11}$, 1998).

There are many studies in which authors compare the efficiency of manual files and that of rotary instruments (Machtou ${ }^{12}$, 1998); stainless steel and nickel-titanium files (Chan, Cheung ${ }^{4}$, 1996; Barthel et al. ${ }^{1}$, 1999) and also the different types of rotary instruments (Blum et al. ${ }^{2}$, 1999; Fabra-Campos, Rodriguez-Vallejo ${ }^{6}, 2001$ and Griffiths et $a l^{7}, 2001$ ), always searching for the best instrumentation.

However, there is a lack of studies related to the instruments evaluated in the present work, especially regarding the removal of dentin promoted by each one of them, both in lateral and mesial directions.

Although Gates-Glidden drills and Flare files are widely discussed individually - their advantages and disadvantages have been reported by Thompson, Dummer ${ }^{19}$ (1998); Svec, Powers ${ }^{18}$ (1999); Fabra-Campos, Rodriguez-Vallejo ${ }^{6}$ (2001) and Griffiths et l. $^{7}$ (2001) -, there are not enough studies comparing the amounts of dentin removed by them.

Comparing the data of groups A and B (lateral flare) one can observe that: a) there was statistical

\section{REFERENCES}

1. Barthel CR, Grubber S, Roulet JFA. New method to assess the results of instrumentation techniques in the root canal. J Endod 1999;25(8):535-8.

2. Blum JY, Machtou P, Micallef JP. Location of contact areas on rotary Profile instruments in relationship to the forces developed during mechanical preparation on extracted teeth. Int Endod J 1999;32(2):108-14. difference of 5\%; b) Gates-Glidden drills removed more dentin in sections 1 and 2; and c) Flare files acted more on section 3 , due, probably, to the design of the instrument.

In groups $\mathrm{C}$ and $\mathrm{D}$ (mesial flare) the instruments presented a similar behavior - no statistically significant difference was observed.

Thus, we can conclude that Gates-Glidden drills can be utilized, as well as the instruments confected with new alloys and designs, considering the removal of dentin. The dentist can choose between Gates-Glidden drills and Flare files, considering not only the anatomic feature of the tooth, but also, the professional's ability and personal preferences, without compromising the result, which is the shaping of the root canal. According to the results of this study, Gates-Glidden burs can be employed to prepare the initial portions of the cervical third, and Flare files can be utilized to more effectively reach and remove the dentin of the deepest portions of the root canal.

The association between scientific knowledge and good sense is important in order to solve each difficulty in the treatment of the root canal - the professional can put together new information, not necessarily utilizing a specific technique.

\section{CONCLUSIONS}

1. There was no significant difference between the removal promoted by both instruments, in the $1^{\text {st }}$ and $2^{\text {nd }}$ millimeters.

2 . On the $3^{\text {rd }}$ millimeter, Flare files promoted greater removal than Gates-Glidden drills, and the difference was statistically significant $(p>0.05)$.

3 . As to mesial increase, the instruments presented a similar behavior.

4. On the $2^{\text {nd }}$ and $3^{\text {rd }}$ millimeters, Gates-Glidden drills promoted mesial detour. There was statistically significant difference ( $p>0.05$ ) as to dentin removal in this direction, when compared to lateral direction.

5. Flare instruments did not present any statistically significant difference when mesial and lateral directions were compared.
3. Buchanan LS. The standardized-taper root canal preparation, part 1: concepts for variably tapered shaping instruments. Dent Today 1998;17(5):54-60.

4. Chan AW, Cheung GSP. A comparison of steel and nickeltitanium K-files in curved canals. Int Endod $\mathrm{J}$ 1996;29(6):370-5. 
Busquim SSK, Santos M dos. Cervical shaping in curved root canals: comparison of the efficiency of two endodontic instruments. Pesqui Odontol Bras 2002;16(4):327-331.

5. Di Donato BHA. Estudo comparativo da aplicação das técnicas de instrumentação seriada e escalonada anatômica em raízes mesiais de molares inferiores humanos. [Tese de Mestrado]. Taubaté: Universidade de Taubaté; 2000.

6. Fabra-Campos H, Rodriguez-Vallejo J. Digitization, analysis and processing of dental images during canal preparation with Quantec Series 2000 instruments. Int Endod J 2001;34(1):29-39.

7. Griffiths T, Chassot AL, Nascimento MF, Bryant ST, Dummer PMH. Canal shapes produced sequentially during instrumentation with Quantec SC rotary nickel-titanium instruments: a study in simulated canals. Int Endod $\mathrm{J}$ 2001;34(2):107-12.

8. Hudson DA, Remeikis NA, Van Cura JE. Instrumentation of curved root canals: a comparison study. J Endod 1992;18(9):448-50.

9. Hülsmann M, Gambal A, Bahr R. An improved technique for the evaluation of root canal preparation. J Endod 1999;25(9):599-602.

10. Leonardo ML, Leal JM. Endodontia: tratamento de canais radiculares. $2^{a}$ ed. São Paulo: Panamericana; 1991.

11. Macedo MCS. Avaliação do desgaste do terço cervical dos canais mesiovestibulares de molares superiores submetidos a diferentes procedimentos de preparo de suas entradas. [Tese de Mestrado]. São Paulo: Faculdade de Odontologia USP; 1998.
12. Machtou P. Endodontic canal preparation: advances in rotary instrumentation. Pract Periodontics Aesthet Dent 1998; 10(7):937-40.

13. Marroquin BB. An anti-zipping preparation system (method and instrument) for curved root canals: a preliminary report. J Endod 1996;22(2):85-9.

14. Nagy CD, Bartha K, Bernáth M, Verdes E, Szabó J. A comparative study of seven instruments in shaping the root canal in vitro. Int Endod $J$ 1997;30(2):124-32.

15. Nagy CD, Bartha K, Bernáth M, Verdes E, Szabó J. The effect of root canal morphology on canal shape following instrumentation using different techniques. Int Endod $\mathrm{J}$ 1997;30(2):133-40.

16. Paiva JG, Antoniazzi JH. Endodontia: bases para a prática clínica. $2^{\text {a }}$ ed. São Paulo: Artes Médicas; 1988.

17. Pesce HF, Medeiros JMF, Moura AAM. Análise morfológica comparativa do preparo de canais radiculares curvos com dois tipos de instrumentos endodônticos. Rev Odontol Univ São Paulo 1997;11(2):87-91.

18. Svec TAS, Powers JM. Torsional strength of Gates Glidden drills exposed to clinical conditions. J Endod 1999;25(2):126-7.

19. Thompson AS, Dumer PMH. Shaping ability of Quantec Series 2000 rotary nickel-titanium instruments in simulated root canals: part 2. Int Endod J 1998;31(4):268-74.

20. Walton RE. Current concepts of canal preparation. Dent Clin North Am 1992;36(2):309-26.

Recebido para publicação em 13/10/01

Enviado para reformulação em 14/06/02

Aceito para publicação em 19/09/02 